\title{
БИОЛОГИЧЕСКИЙ КОНТРОЛЬ ВРЕДИТЕЛЕЙ СЕЛЬСКОХОЗЯЙСТВЕННЫХ КУЛЬТУР С ИСПОЛЬЗОВАНИЕМ МЕТОДА АВТОДИССЕМИНАЦИИ ЭНТОМОПАТОГЕННЫХ НЕМАТОД СЕМЕЙСТВА Steinermatidae (Nematoda: Rhabditida)*
}

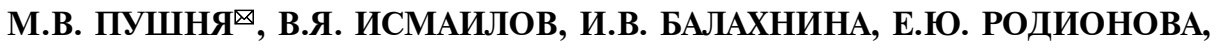 \\ Е.Г. СНЕСАРЕВА, А.А. КОМАНЦЕВ
}

В настоящее время разработка приемов биологизированной защиты агроценозов от вредных членистоногих составляет одну из важнейших проблем при создании агросистем будущего, которая затрагивает множество аспектов - от эффективности и продуктивности растениеводства до социального и экологического благополучия и природосбережения. Эффективная биозащита агроценозов невозможна без сочетания разнообразных биоагентов и приемов регулирования численности вредителей. Одним из элементов улучшения ситуации в агроценозах служит применение патогенов вредных организмов и синтетических половых феромонов. В предлагаемой работе показана возможность использования энтомопатогенных нематод (ЭПН) семейства Steinernematidae Filipjev, 1934 как агента автодиссеминации в агроэкосистемах сои, кукурузы и яблоневого сада и описано влияние этих патогенов на разные группы организмов, населяющих биоценозы (в частности, продемонстрировано снижение численности вредных насекомых и повышение активности природных полезных энтомопатогенов). Суть метода заключается в направленном введении в агроценоз энтомопатогенов-биоагентов посредством их аппликации на привлеченных насекомых, отловленных в ловушки, и создании таким образом эпизоотий в популяциях целевых видов. Ранее энтомопатогенные нематоды не использовались в качестве агентов автодиссеминации в борьбе с супердоминантными видами - яблонной плодожоркой Cydia ротоnella L., 1758 и жуками-щелкунами семейства Elateridae Leach, 1815, кроме того, их влияние на других представителей энтомофауны агроэкоценозов также не изучалось. Цель этой работы оценка эффективности метода автодиссеминации ЭПН на различных культурах. Предпосылкой для проведения представляемого исследования стала успешная апробация метода диссеминации вируса гранулеза, проведенная ранее в яблоневом саду, и предварительные испытания метода автодиссеминации ЭПН для борьбы со щелкунами. В работе применяли два вида патогенов из семейства Steinernematidae - Steinernema carpocapsae (Weiser, 1955) и St. feltiae (Filipiev, 1934), размноженных в лабораторных условиях на разных насекомых-хозяевах. Выполненные эксперименты показали, что энтомопатогенные нематоды, инокулируемые в агроценозы с помощью специально разработанных авторских препаративных форм и модификаций феромонных ловушек, поражали нематодно-бактериальным комплексом 60,0-100\% жуков-щелкунов семейства Elateridae и 34,0-35,3 \% имаго яблонной плодожорки $C$. pomonella и восточной плодожорки Grapholitha molesta (Busck, 1916), что предполагает при дополнительном внесении дальнейшее накопление агентов биологической борьбы в почве защищаемых агроценозов. Заметный положительный эффект автодиссеминации ЭПН проявлялся в снижении поврежденности плодов яблони плодожоркой на $10,0 \%$ и всходов кукурузы и сои на $13,2 \%$ в сравнении с участками, где проводились химические обработки. При использовании рассматриваемого метода не выявлено отрицательного воздействия энтомопатогенных нематод на энтомофагов, таких как златоглазки (Chrysopidae Schneider, 1851), и перепончатокрылых паразитов из семейств Braconidae Latreille, 1829 и Ichneumonidae Latreille, 1802, поражающих насекомых-вредителей. При этом в саду, где проводились испытания, регистрировалось увеличение зараженности гусениц $C$. pomonella перепончатокрылыми (+15\%). Установлено стимулирующее воздействие энтомопатогенов на активность аборигенных почвенных нематод, присутствующих в почве исследуемых ценозов, что проявлялось в увеличении числа энтомопатогенных нематод, отловленных на тест-объект (в 1,52,0 раза в сравнении с пробами перед обработками). Важен и тот факт, что эффект автодиссеминации оказался пролонгированным и проявился и на следующий год после ее применения как в яблоневом саду, так и в севообороте сельскохозяйственных культур.

Ключевые слова: биоконтроль, энтомопатогенные нематоды, автодиссеминация, почвенные нематоды, яблонная плодожорка, жуки-щелкуны, проволочники, феромонные ловушки, яблоня, кукуруза. соя.

\section{Избыточное применение химических пестицидов в России вызывает}

\footnotetext{
* Исследования выполнены в рамках Государственного задания Министерства науки и высшего образования
} РФ по теме № 0686-2019-0010. 
тревогу за безопасность продукции и чистоту окружающей среды, поэтому в современных условиях новой стратегией защиты растений от вредных организмов становится использование природных регуляторов биоценотических отношений в агросистемах (1).

Управление численностью вредителей важнейших сельскохозяйственных культур с использованием биологических средств и методов, развитие которых в настоящее время составляет научный приоритет, невозможно без широкого использования синтетических половых феромонов насекомых (1-5). Применение этих аттрактантов для мониторинга, массового отлова и нарушения репродуктивных связей (дезориентации) фитофагов имеет широкое распространение во всем мире, однако этот подход еще не исчерпал себя (6-11). Например, для многих видов насекомых установлено, что при повышении концентрации синтетического полового феромона в агроценозе отмечается уменьшение яйцепродукции у самок, удлинение периода развития и уменьшение выживаемости преимагинальных стадий, что, в частности, успешно продемонстрировано в саду против яблонной и восточной плодожорок $(4,12-15)$. Поиск новых приемов применения половых феромонов насекомых с целью управления их численностью привел к открытию оригинальных методов биологического контроля вредителей на основе диссеминации феромонов и автодиссеминации энтомопатогенов целевых видов с помощью феромонных ловушек с апплицирующими устройствами $(15,16)$.

К числу эффективных природных биоагентов принадлежат энтомопатогенные нематоды (ЭПН) семейств Steinernematidae Filipjev, 1934 и Heterorhabditidae Poinar, 1976. Эти организмы способны заражать более тысячи видов членистоногих, многие из которых относятся к опасным вредителями важнейших сельскохозяйственных культур (17-20). Среди биосредств, производимых в мире, нематодные препараты находятся на втором месте после бактериальных (21-25). ЭПН обладают способностью самостоятельно проникать в жертву, сохраняться в погибших насекомых и способствуют инвазии в тело насекомых других патогенов (в частности, вирусов и бактерий) энтомопатогенных паразитов. Высокая скорость развития нематод (в организме живого хозяина в течение 6-10 сут) позволяет им распространяться с личинками и имаго вредителей (26-31). Единственный фактор, лимитирующий широкое распространение препаратов на основе ЭПН, - их высокая гигрофильность. В связи с этим для увеличения жизнеспособности таких используемых биоагентов создаются различные препаративные формы, обеспечивающие достаточное и пролонгированное влагообеспечение нематод (17, 23-26). Важно и то, что указанные патогены, взаимодействуя с другими консорбентами биоценоза, могут также выполнять микрорегуляторную роль в формировании почвенной структуры $(32,33)$. Особенности биологии ЭПН предполагают возможность насыщения ими почв агроценозов с помощью самцов, отловленных феромонными ловушками с устройствами (аппликаторами), заражающими привлеченных насекомых энтомопатогенными нематодами (метод автодиссеминации энтомопатогенов). Во многих исследованиях показана высокая биологическая эффективность ЭПН против проволочников (личинки жуков-щелкунов семейства Elateridae) и яблонной плодожорки Cydia pomonella, L., 1758, причем рассматривались различные способы их применения (23, 34-36).

На этой основе нами был предложен новый способ применения энтомопатогенных нематод методом их автодиссеминации, обеспечивающим 
их большую продолжительность жизни, активность и скорость распространения в стации. Метод основан на внутри- и межвидовой химической коммуникации и положительном светотаксисе видов насекомых, привлекаемых с помощью синтетических половых феромонов или света в разработанные апплицирующие устройства (16). Покидающие аппликатор насекомые выступают в качестве агентов - носителей ЭПН, применяемых для защиты сельскохозяйственных культур от доминантных вредителей $(16,35)$.

Цель представленных исследований состояла в изучении возможности использования феромонных ловушек для автодиссеминации энтомопатогенных нематод в качестве агентов биоконтроля яблонной плодожорки Cydia pomonella L., 1758 и жуков-щелкунов семейства Elateridae Leach, 1815 и их влияния на представителей полезной фауны изучаемых агроценозов.

Методика. В экспериментах использовали энтомопатогенных нематод семейства Steinernematidae трех видов и четырех варитетов: Steinernema feltiae (Filipiev, 1934), St. kraussei Steiner, 1923, St. carpocapsae (Weiser, 1955), St. carpocapsae var. "agriotes" (Weiser, 1955) из коллекции полезных организмов ФНЦБЗР (Федеральный научный центр биологической защиты растений). Вид St. kraussei исходно получен из коллекции Всероссийского НИИ фундаментальной и прикладной паразитологии животных и растений РАН (ВНИИП, г. Москва), виды St. feltiae и St. carpocapsae var. "agriotes" из коллекции Всероссийского НИИ защиты растений (ВИЗР, г. Санкт-Петербург-Пушкин); St. carpocapsae - местный варитет, обнаруженный в яблоневом саду в станице Ленинградской (Краснодарский край).

Накопление ЭПН осуществляли в камере искусственного климата MLR 35 OH («Panasonic», Япония) с использованием лабораторных насекомых-хозяев - большой восковой моли Galleria melonella (Linnaeus, 1758) и большого мучного хрущака Tenebrio molitor Linnaeus, 1758. Применяли способы, описанные Л.Г. Даниловым (24), с предложенными нами модификациями $(35,36)$.

Обнаружение энтомопатогенных нематод в почвенных образцах из изучаемых биотопов осуществлялось по методике, предложенной С.Э. Спиридоновым (27), с использованием гусениц G. melonella (по 10 экз. в каждом варианте), которых помещали в образцы почв, отобранные на контрольных участках, а также на участках, где проводилась автодессеминация. Через 1 нед гусениц извлекали и выявляли наличие энтомопатогенов с помощью микроскопа при 90-кратном увеличении (Биолам, «ЛОМО», Россия); образцы почв также просматривали под бинокулярным микроскопом при 10-кратном увеличении (МБС-10, «ЛЗОС», Россия) (27).

Энтомопатогенов после автодиссеминации выявляли в имаго, личинках и гусеницах с помощью так называемых «нематодных ловушек» и при просмотре биоматериала под микроскопом при 90-кратном увеличении (Биолам, «ЛОМО», Россия).

Для заражения трех видов щелкунов - кубанского Agriotes tauricus Heyden, 1882, посевного A. sputator (Linnaeus, 1758) и степного A. gurgistanus (Faldermann, 1835) использовали стандартные модифицированные ловушки типа Эстрон (производство ФГБНУ Всероссийский центр карантина растений, Московская обл.) в насекомоприемники которых помещали поролоновую губку размером $45 \times 95$ мм, пропитанную суспензией ЭПН (титр инвазионных личинок $-2,5 \times 10^{6} /$ мл). Чтобы обеспечить свободную миграцию отловленных насекомых в окружающую среду, в насекомоприемнике проделывали летное отверстие диаметром 35 мм. Ловушки 
(по 10 шт. в каждом варианте) выставляли в зависимости от начала лёта каждого из изучаемых видов жуков-щелкунов, распределяли равномерно на участках сои и кукурузы на расстоянии 30-40 м друг от друга методом конверта. Для изоляции вариантов опыта друг от друга соответствующие участки размещали на расстоянии 200 м. Нанесение свежеприготовленной суспензии нематод на губки и отбор проб проводили каждые 7-10 сут в течение всего периода лёта насекомых. Для учета отловленных самцов щелкунов половину ловушек оставляли без летного отверстия, далее из них отбирали жуков и в лабораторных условиях определяли число зараженных особей и число выделившихся из них инвазионных личинок энтомопатогенных нематод.

Для диссеминации ЭПН в яблоневом саду использовали стандартные модифицированные ловушки типа Атракон-А (изготовлены нами в лаборатории из бумаги типа Тетрапак). Повторность опытов также составляла по 10 ловушек в каждом варианте. С целью аппликации нематод на поверхность вкладыша помещали поролоновую губку размером $20 \times 20$ мм, содержащую суспензию энтонематод с титром инвазионных личинок $2,5 \times 10^{6}$ ммл. Для определения числа зараженных нематодами гусениц мы использовали ловушки с клеевыми вкладышами, для дальнейшего распространения ЭПН в агроценозе в половине ловушек клей на вкладыши не наносили.

Нанесение свежеприготовленной суспензии нематод на губки и отбор проб проводили каждые 7-10 сут (такая периодичность смены биопрепарата для обеспечения эффективности воздействия нами была определена ранее в исследованиях со щелкунами) (35). Для учета числа пораженных энтомопатогенами насекомых их отбирали из ловушек и ловчих поясов, степень зараженности имаго и личинок определяли в лабораторных условиях.

Полевые исследования для яблонной плодожорки проводили в яблоневых садах учхоза «Кубань» (ФГБОУ ВО Кубанский государственный аграрный университет им. И.Т. Трубилина, г. Краснодар и ФНЦБЗР), для жуков-щелкунов - в научном севообороте ФНЦБЗР в течение 2011-2015 годов. Зараженных насекомых отлавливали на площади 1 га. Данные по числу отловленных зараженных насекомых сравнивали с аналогичными показателями на контрольных участках, где применялась химическая защита, которые находились на расстояние не менее 500 м от опытных участков.

Энтомофагов выделяли после отбора гусениц яблонной плодожорки из ловчих поясов с последующим индивидуальным выведением.

Идентификацию собранного биоматериала проводили с использованием фундаментальных определителей Зоологического института РАН (г. Санкт-Петербург) и Дальневосточного отделения РАН (г. Владивосток) $(37,38)$, применяя камеры искусственного климата MLR 35 OH для содержания гусениц и куколок яблонной плодожорки, что обеспечивало либо вылет энтомофагов из зараженных насекомых, либо вылет бабочек, и микроскопирование (бинокулярный микроскоп МБС-10 с 8-кратным увеличением, «ЛЗОС», Россия).

Полученные результаты обрабатывали по общепринятым методикам статистического анализа по Б.А. Доспехову (39) и с применением программы Statistica 12.6 («StatSoft, Inc.», США). В таблицах и на рисунках представлены средние $(M)$ и стандартные ошибки среднего ( $\pm \mathrm{SEM})$. Достоверность различий между вариантами определяли с помощью $t$-критерия Стьюдента при $\mathrm{P} \geq 0,95$.

Результаты. Широкий лабораторный скрининг энтомопатогенных нематод из коллекции ФНЦБЗР, отобранных из различных биотопов Крас- 
нодарского края, позволил нам выявить наибольшую активность трех видов патогенов - St. carpocapsae, St. feltiae и St. kraussei в отношении гусениц $G$. pomonella и двух видов - St. carpocapsae var. "agriotes" и St. feltiae - в отношении проволочников $(35,36)$. В соответствии с этим указанные виды использовали в дальнейших исследованиях.

Поскольку энтомопатогенные нематоды достаточно широко распространены в некоторых биоценозах, а основным местом их обитания служит почва, для изучения влияния привносимых патогенов на аборигенную патофауну предварительно проанализировали почвы из биотопов, где планировалось проведение экспериментов. В образцах из яблоневого сада ФНЦБЗР, который активно эксплуатируется в течение нескольких лет, были выявлены энтомопатогенные нематоды семейства Steinernematidae St. carpocapsae и Steinernema sp., поэтому для диссеминации мы выбрали вид St. feltiae, который не встречается в выбранной для эксперимента экосистеме. По нашим наблюдениям и данным, полученным ранее (40), для пропашных культур в севообороте характерны низкая численность или практически полное отсутствие этих патогенов. Сходная ситуация наблюдалась в 2013 году в саду учхоза «Кубань», который был выведен из эксплуатации за 2 года до проводимых исследований: число ЭПН видов St. carpocapsae и Steinernema sp., отловленных на приманочное насекомое, здесь было ниже, чем в саду ФНЦБЗР.

Результаты проведенных испытаний автодиссеминации ЭПН против жуков-щелкунов показали, что наибольшую опасность для всходов сои и кукурузы представляет кубанский щелкун. Число отловленных в феромонные ловушки особей в опытных вариантах составляло в 2011 году

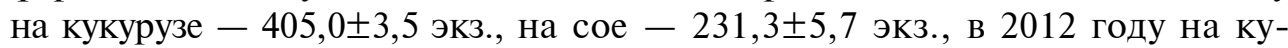

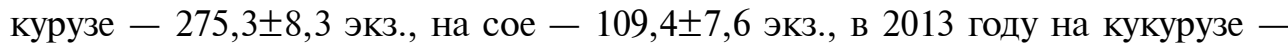

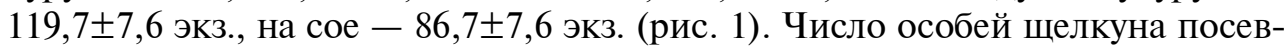
ного было ниже и составляло в 2011 году на кукурузе $-101,3 \pm 2,4$ экз., на

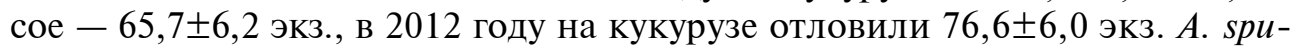

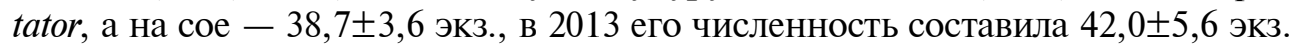
на кукурузе и $32,0 \pm 3,6$ экз. на сое (см. рис. 1). Уловистость самцов степного щелкуна в опытные феромонные ловушки была минимальной и составляла

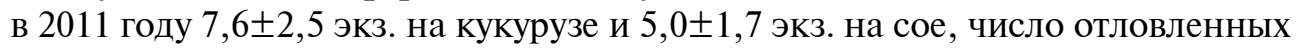

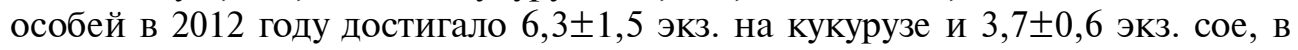

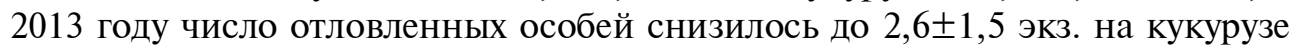
и $1,3 \pm 0,5$ экз. на сое (см. рис. 1$)$.

Таким образом, при применении метода автодиссеминации в течение 3 лет наблюдалось снижение числа насекомых, пойманных в феромонные ловушки, тогда как в контроле численность щелкунов либо не изменялась, как в случае со степным щелкуном (число особей, отловленных в 2011-

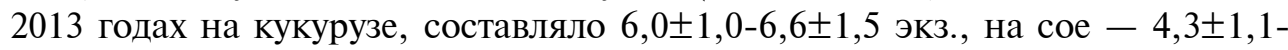
$5,3 \pm 0,6$ экз.), либо возрастала, что отмечали для кубанского и посевного щелкунов. Так, численность кубанского щелкуна возросла на кукурузе с

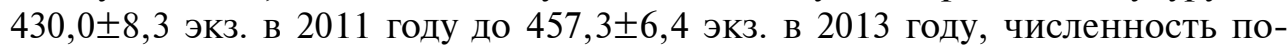

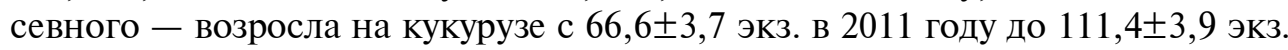
в 2013 году, на сое мы также наблюдали увеличение числа самцов посев-

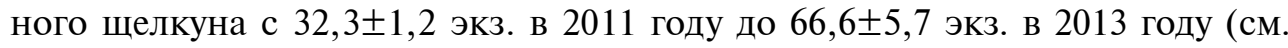
рис. 1). Также происходило некоторое снижение числа отловленных самцов

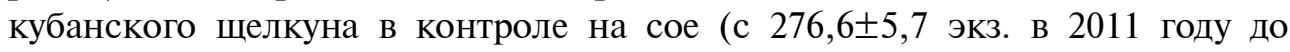
$240,0 \pm 9,6$ эк3. в 2013 году), однако различия с опытными вариантами оставались статистически значимыми при $\mathrm{P} \geq 0,95$ (см. рис. 1). 

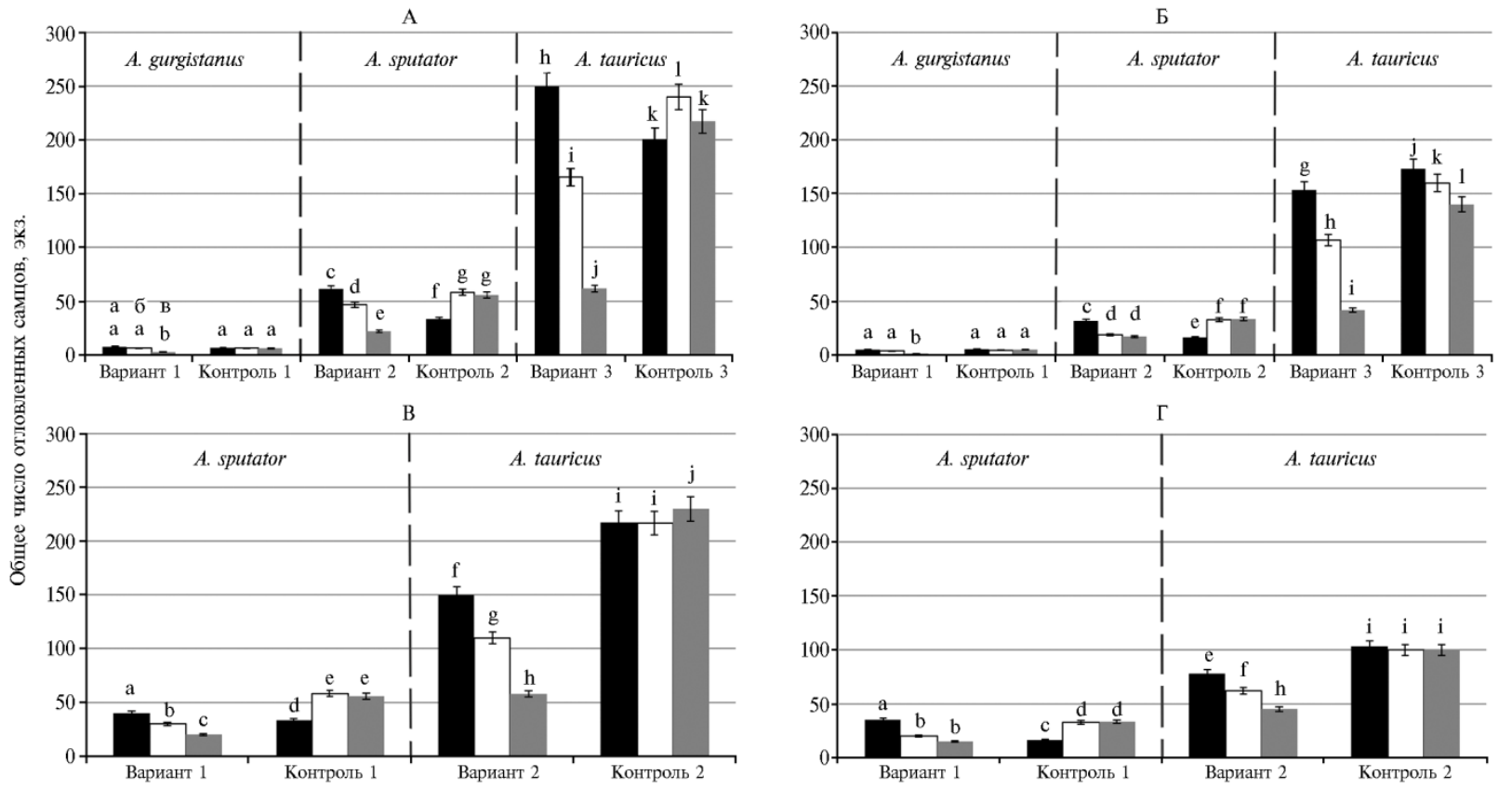

Рис. 1. Численность щелкунов рода Agriotes при внесении нематод методом автодиссеминации на посевах в разные годы: А и Б - нематода Steinernema carpocapsae, соответственно посевы кукурузы и сои, В и Г - нематода St. feltiae, соответственно посевы кукурузы и сои; 1-3 - варианты с внесением нематод, контроль без внесения; а, б, в - соответственно 2011, 2012 и 2013 годы ( $n=10, M \pm \mathrm{SEM}$, севооборот ФНЦБЗР, Краснодарский край). Разными буквами отмечены статистически значимые различия между вариантами при $\mathrm{P} \geq 0,95$. Описание вариантов см. в разделе «Методика». 
1. Результативность метода автодиссеминации энтомопатогенных нематод Steinernema carpocapsae и St. feltiae против щелкунов рода Agriotes на посевах кукурузы и сои в разные годы ( $n=10, M \pm \mathrm{SEM}$, севооборот ФНЦБЗР, Краснодарский край)

\begin{tabular}{|c|c|c|c|c|c|c|c|c|c|c|}
\hline \multirow{4}{*}{ Вид щелкунов } & \multirow{4}{*}{ Вид нематод } & \multicolumn{9}{|c|}{ Отловлено самцов, экз. } \\
\hline & & \multicolumn{3}{|c|}{2011 год } & \multicolumn{3}{|c|}{2012 год } & \multicolumn{3}{|c|}{2013 год } \\
\hline & & \multirow{2}{*}{ всего, экЗ. } & \multicolumn{2}{|c|}{ заражены } & \multirow{2}{*}{ всего, экз. } & \multicolumn{2}{|c|}{ заражены } & \multirow{2}{*}{ всего, эКз. } & \multicolumn{2}{|c|}{ заражены } \\
\hline & & & всего, эКЗ. & $\%$ & & всего, эКз. & $\%$ & & всего, эКз. & $\%$ \\
\hline \multicolumn{11}{|c|}{ Кукуруза } \\
\hline A. sputator & \multirow[t]{2}{*}{ St. carpocapsae } & $73,0 \pm 7,0$ & $65,0 \pm 5,6$ & 89,0 & $54,0 \pm 5,6$ & $54,0 \pm 5,6$ & 90,0 & $55,0 \pm 4,6^{\mathrm{a}}$ & $47,0 \pm 6,0$ & 85,4 \\
\hline Контроль & & $63,0 \pm 4,6$ & 0 & 0 & $75,0 \pm 6,0$ & 0 & 0 & $87,0 \pm 5,0$ & 0 & 0 \\
\hline \multirow{2}{*}{$\begin{array}{l}\text { A. sputator } \\
\text { Контроль }\end{array}$} & \multirow[t]{2}{*}{ St. feltiae } & $40,0 \pm 5,0$ & $32,0 \pm 3,5$ & 80,0 & $26,0 \pm 1,8$ & $26,0 \pm 1,8$ & 86,7 & $23,0 \pm 2,6^{c}$ & $20,0 \pm 3,3$ & 86,9 \\
\hline & & $40,0 \pm 4,0$ & 0 & 0 & $50,0 \pm 5,5$ & 0 & 0 & $60,0 \pm 6,2$ & 0 & 0 \\
\hline \multirow{2}{*}{$\begin{array}{l}\text { A. tauricus } \\
\text { Контроль }\end{array}$} & \multirow[t]{2}{*}{ St. carpocapsae } & $150,0 \pm 10,3$ & $147,0 \pm 7,8$ & 98,0 & $88,0 \pm 2,7$ & $88,0 \pm 2,7$ & 97,7 & $60,0 \pm 7,2^{\mathrm{e}}$ & $57,0 \pm 5,2$ & 95,0 \\
\hline & & $150,0 \pm 8,0$ & 0 & 0 & $160,0 \pm 9,3$ & 0 & 0 & $160,0 \pm 9,6$ & 0 & 0 \\
\hline \multirow{2}{*}{$\begin{array}{l}\text { A. tauricus } \\
\text { Контроль }\end{array}$} & \multirow[t]{2}{*}{ St. feltiae } & $68,0 \pm 4,6$ & $61,0 \pm 6,2$ & 89,7 & $33,0 \pm 3,6$ & $33,0 \pm 3,6$ & 94,2 & $25,0 \pm 4,3^{\mathrm{g}}$ & $23,0 \pm 4,3$ & 92,0 \\
\hline & & $70,0 \pm 4,3$ & 0 & 0 & $79,0 \pm 6,2$ & 0 & 0 & $85,0 \pm 6,5$ & 0 & 0 \\
\hline A. gurgistanus & \multirow{3}{*}{ St. carpocapsae } & $7,0 \pm 1,8$ & $6,0 \pm 3,6$ & 85,7 & $4,0 \pm 1,0$ & $4,0 \pm 1,0$ & 80,0 & $4,0 \pm 2,5^{\mathrm{i}}$ & $3,0 \pm 1,2$ & 75,0 \\
\hline \multirow[t]{2}{*}{ Контроль } & & $5,0 \pm 2,5$ & 0 & 0 & $6,3 \pm 1,5$ & 0 & 0 & $7,0 \pm 1,0$ & 0 & 0 \\
\hline & & & & & $\mathrm{Cоя}$ & & & & & \\
\hline \multirow{2}{*}{$\begin{array}{l}\text { A. sputator } \\
\text { Контроль }\end{array}$} & \multirow{2}{*}{ St. carpocapsae } & $30,0 \pm 6,1$ & $27,0 \pm 4,3$ & 90,0 & $23,0 \pm 3,6$ & $23,0 \pm 3,6$ & 92,0 & $15,0 \pm 2,6$ & $15,0 \pm 2,6$ & 83,3 \\
\hline & & $31,0 \pm 4,8$ & 0 & 0 & $38,0 \pm 3,6$ & 0 & 0 & $43,0 \pm 6,9$ & 0 & 0 \\
\hline \multirow{2}{*}{$\begin{array}{l}\text { A. sputator } \\
\text { Контроль }\end{array}$} & \multirow[t]{2}{*}{ St. feltiae } & $17,0 \pm 3,6$ & $15,0 \pm 2,8$ & 88,2 & $8,0 \pm 1,6$ & $8,0 \pm 1,6$ & 80,0 & $7,0 \pm 1,6$ & $7,0 \pm 1,6$ & 87,5 \\
\hline & & $15,0 \pm 4,2$ & 0 & 0 & $21,0 \pm 2,6$ & 0 & 0 & $25,0 \pm 3,6$ & 0 & 0 \\
\hline \multirow{2}{*}{$\begin{array}{l}\text { A. tauricus } \\
\text { Контроль }\end{array}$} & \multirow{2}{*}{ St. carpocapsae } & $130,0 \pm 6,2$ & $122,0 \pm 6,9$ & 93,8 & $63,0 \pm 7,9$ & $63,0 \pm 7,9$ & 90 & $47,0 \pm 5,3$ & $47,0 \pm 5,3$ & 79,6 \\
\hline & & $130,0 \pm 7,9$ & 0 & 0 & $146,0 \pm 8,5$ & 0 & 0 & $150,0 \pm 6,6$ & 0 & 0 \\
\hline \multirow{2}{*}{$\begin{array}{l}\text { A. tauricus } \\
\text { Контроль }\end{array}$} & \multirow[t]{2}{*}{ St. feltiae } & $50,0 \pm 4,9$ & $45,0 \pm 5,3$ & 90,0 & $26,0 \pm 4,0$ & $26,0 \pm 4,0$ & 92,8 & $21,0 \pm 2,1$ & $21,0 \pm 2,1$ & 95,4 \\
\hline & & $48,0 \pm 5,2$ & 0 & 0 & $53,0 \pm 6,3$ & 0 & 0 & $60,0 \pm 6,5$ & 0 & 0 \\
\hline \multirow{2}{*}{$\begin{array}{l}\text { A. gurgistanus } \\
\text { Контроль }\end{array}$} & St. carpocapsae & $5,0 \pm 1,5$ & $3,0 \pm 0,8$ & 60,0 & $2,0 \pm 0,4$ & $2,0 \pm 0,4$ & 66,7 & $2,0 \pm 0,2$ & $2,0 \pm 0,2$ & 100 \\
\hline & & $4,0 \pm 1,3$ & 0 & 0 & $6,0 \pm 1,8$ & 0 & 0 & $5,0 \pm 1,3$ & 0 & 0 \\
\hline
\end{tabular}

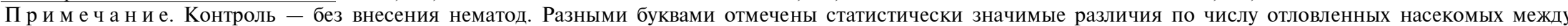
опытными и контрольными вариантами в разные годы и на разных культурах при $\mathrm{P} \geq 0,95$. 
Период гибели имаго составлял 4-5 сут, что создавало условия для распространения инфекции. Доля особей, зараженных нематодами St. carpocapsae, достигала для A. sputator 83,3-92,0 \%, для A. tauricus - 79,6-98,0 \%, для A. gurgistanus - 60,0-100 \%, для насекомых, зараженных St. feltiae, значения составили для A. sputator - 80,0-88,2 \%, A. tauricus - 9,7-94,2 \% (табл. 1). Число инвазионных личинок нематод, выделившихся из одного насекомого, составило для A. sputator $8,8 \times 10^{4}$ эк3., для A. gurgistanus $-9,1 \times 10^{4}$ эк3., тогда как для $A$. tauricus - $1,25 \times 10^{5}$ экз., что предполагает привнесение в окружающую среду более 10 млн особей энтомопатогенов и активацию природных популяций ЭПН.

Дополнительное внесение нематод в почву, по нашим наблюдениям и как это ранее отмечал Л.Г. Данилов с соавт. (41), может вызывать изменение этологии у насекомых. У проволочников это выражается в том, что зараженные нематодами личинки выползают на поверхность почвы, становясь в результате более доступными для энтомофагов (хищных жужелиц) и позвоночных животных.

Необходимо отметить, что в 2011-2013 годах наблюдалось снижение численности отловленных в феромонные ловушки самцов жуков-щелкунов, а также поврежденности растений кукурузы и сои вредителями на 13,2 \% по сравнению с участками, где применялась традиционная система защиты с использованием химических инсектицидов (обработка семян препаратом Cruiser®, KC, «Syngenta», Швейцария), и не были обнаружены личинки щелкунов в почвенных раскопах, что стало результатом проведенной в 20112013 годах диссеминации энтомопатогенных нематод.

Автодиссеминацию ЭПН в яблоневых садах осуществляли также в течение 3 лет на двух участках с разной интенсивностью проводимых ранее химических обработок. Наши исследования показали возможность использования нематод для автодиссеминации против яблонной плодожорки в саду, поскольку в ловушках по контролю численности в обоих садовых агроценозах были обнаружены бабочки яблонной плодожорки Cydia pomonella, зараженные патогенами, а в саду ФНЦБЗР - и восточной плодожорки Grapholitha molesta (Busck, 1916) (табл. 2). Процент чешуекрылых, в которых были выявлены энтомопатогены, оказался примерно одинаков -30,335,3 \%. Число гельминтов, выделившихся из одного насекомого, составляло для C. pomonella $1 \times 10^{4}$, для G. molesta $-1 \times 10^{3}$ экз. инвазионных личинок.

2. Эффективность метода автодиссеминации энтомопатогенных нематод Steinernema carpocapsae и St. feltiae в яблоневом саду $(n=10, M \pm \mathrm{SEM}$, Краснодарский край, 2013-2015 годы)

\begin{tabular}{|c|c|c|c|c|c|c|c|c|}
\hline \multirow{4}{*}{ Вариант } & \multicolumn{8}{|c|}{ Число отловленных насекомых } \\
\hline & \multicolumn{4}{|c|}{ всего, эКЗ. } & \multicolumn{4}{|c|}{ из них зараженных нематодами, \% } \\
\hline & \multicolumn{2}{|c|}{ фитофагов } & \multicolumn{2}{|c|}{ энтомофагов } & \multicolumn{2}{|c|}{ фитофаги } & \multicolumn{2}{|c|}{ энтомофаги } \\
\hline & ЯП & $\mathrm{B \Pi}$ & 3 & ПП & ЯП & $\mathrm{B} \Pi$ & 3 & ПП \\
\hline \multicolumn{9}{|c|}{ Садучхоза «Кубань» } \\
\hline Опыт & $20,0 \pm 1,7^{\mathrm{a}}$ & 0 & 0 & $20,0 \pm 0,6^{c}$ & 30,3 & 0 & 0 & 0 \\
\hline Контроль & $40,0 \pm 2,2^{b}$ & 0 & 0 & $10,0 \pm 0,8$ & 0 & 0 & 0 & 0 \\
\hline \multicolumn{9}{|c|}{ С а д Ф Н Ц Б 3 Р } \\
\hline Опыт & $37,0 \pm 3,5^{\mathrm{a}}$ & $99,0 \pm 3,5^{\mathrm{e}}$ & $9,0 \pm 1,1^{\mathrm{g}}$ & $62,0 \pm 1,9^{i}$ & 35,3 & 34,0 & 0 & 0 \\
\hline Контроль & $45,0 \pm 3,3^{b}$ & $120,0 \pm 4,1^{\mathrm{f}}$ & $2,0 \pm 0,6^{\mathrm{h}}$ & $10,0 \pm 1,7 \mathrm{j}$ & 0 & 0 & 0 & 0 \\
\hline $\begin{array}{l}\text { П р и м е ч а } \\
\text { восточная пл } \\
\text { Hymenoptera. } \\
\text { мых между о }\end{array}$ & $\begin{array}{l}\text { I е. Контро } \\
\text { ожорка } G r \\
\text { зными бук } \\
\text { тными и к }\end{array}$ & $\begin{array}{l}\text { - без внес } \\
\text { holitha moles } \\
\text { ми отмечен } \\
\text { Ітрольными }\end{array}$ & $\begin{array}{l}\text { ния немат } \\
t, 3-\text { зла } \\
\text { статистич } \\
\text { ариантам }\end{array}$ & $\begin{array}{l}\text { д. ЯП }- \text {, } \\
\text { оглазка } C \\
\text { ски значи } \\
\text { при } \mathrm{P} \geq 0,\end{array}$ & $\begin{array}{l}\text { онная п } \\
\text { soperla } \\
\text { е различ }\end{array}$ & $\begin{array}{l}\text { орка С } \\
\text { ПК - } \\
\text { числу }\end{array}$ & $\begin{array}{l}\text { pото } \\
\text { епон }\end{array}$ & $\begin{array}{l}\text {, ВП - } \\
\text { крылы }\end{array}$ \\
\hline
\end{tabular}

В результате испытаний в саду, как и в севообороте пропашных культур, было выявлено снижение числа насекомых, отловленных в ловушки. 
Отмечалось уменьшение поврежденности плодов (примерно на 10 \%) по сравнению с участками, где применялись стандартные системы защиты, учитывая, что даже в экологических садах проводится как минимум 4-5 обработок различными химическими препаратами (6).

При этом среди отловленных энтомофагов - златоглазок Chrysoperla carnea St. и перепончатокрылых (отряд Hymenoptera Linnaeus, 1758) семейства Braconidae Latreille, 1829, в частности Ascogaster quadridentatus Wesmael, 1835, A. rufidens Wesmael, 1835, Microdus rufipas Nees, 1814, а также семейства Ichneumonidae Latreille, 1802, которое было представлено видами Liotryphon crassisetus (Thomson, 1877), L. caudatus (Ratzeburg, 1848) и L. punctulatus (Ratzeburg, 1848), насекомых, зараженных нематодами, мы не выявили.

Иными словами, определенные группы энтомофагов оказались толерантными к воздействию энтомонематод. Еще в 2008 году С.Г. Даниловым и соавт. (41) было высказано предположение о том, что постоянное, проводившееся в течение ряда лет применение ЭПН в яблоневом саду способствует повышению как количественного, так и качественного разнообразия видового состава энтомофагов. В нашем исследовании эта гипотеза нашла подтверждение. Так, число представителей Hymenoptera, выявленных во второй половине августа, было значительно больше. При этом в саду ФНЦБЗР, где проводились испытания метода, мы регистрировали увеличение видового разнообразия перепончатокрылых (с четырех видов до шести) и зараженности гусениц C. pomonella с $6 \%$ до $15 \%$ (рис. 2).

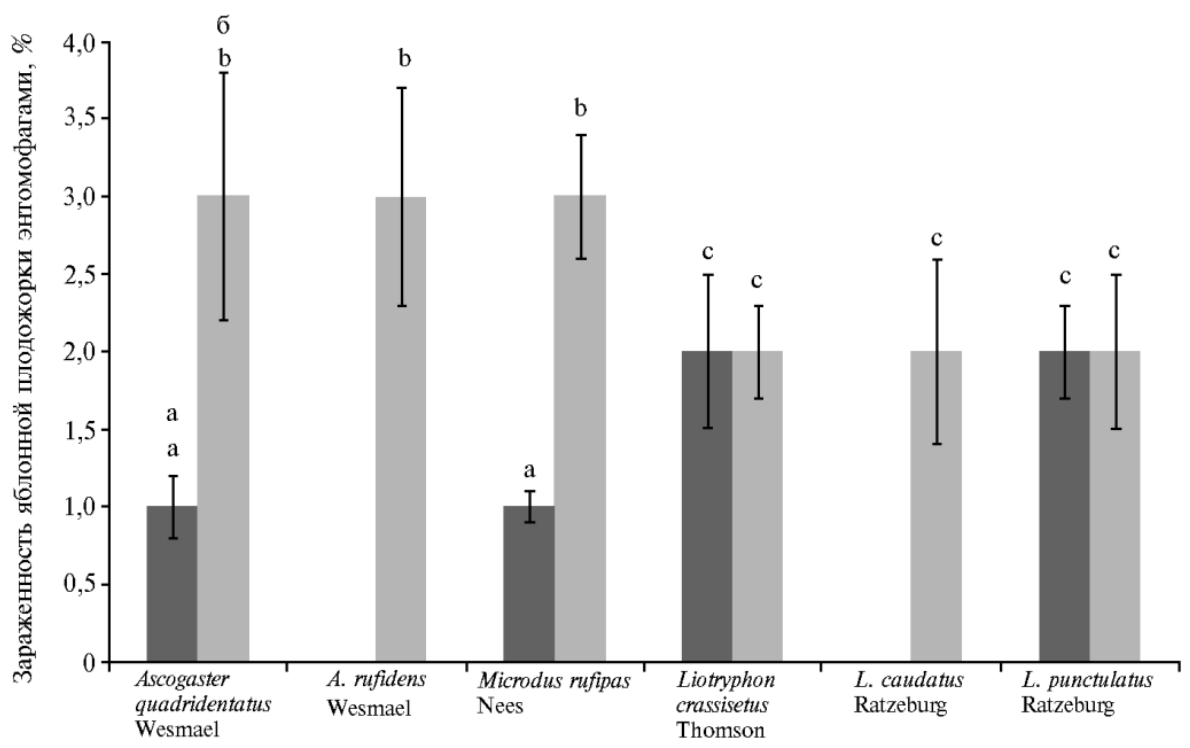

Рис. 2. Зараженность яблонной плодожорки Cydia pomonella энтомофагами семейств Braconidae и Ichneumonidae (отряд Hymenoptera) в 2013 году (а) и в 2015 году (б) (общий объем выборки -

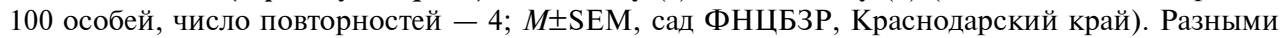
буквами отмечены статистически значимые различия по числу энтомофагов в разные годы исследований при $\mathrm{P} \geq 0,95$.

В ряде работ сообщается $(16,42,43)$, что в качестве агентов автодиссеминации, причем довольно успешно, в ловушках различного типа (феромонных, световых и т.д.) используются преимущественно энтомопатогенные грибы и вирусы. Внесение энтомопатогенных нематод осуществляется в основном традиционными методами - при опрыскивании, внесении в почву перед посевом сельскохозяйственных культур, при поливе, обработке приствольных кругов в садах и другими способами $(21,44,45)$. Предлагаемый 
нами метод биологического контроля вредителей посредством автодиссеминации ЭПН позволяет расширить набор приемов для применения этих энтомопатогенов.

Результаты наших исследований продемонстрировали, что автодиссеминация ЭПН благоприятно сказывалась и на повышении инвазионной активности природных популяций энтомогельминтов в яблоневом саду. Так, почвенные биотесты с использованием G. melonella показали увеличение числа инвазионных личинок ЭПН вида St. carpocapsae в расчете на одну гусеницу через 2 мес после проведения автодиссеминации по сравнению с результатами, полученными перед проведением экспериментов (табл. 3). Увеличение активности местных популяций патогенов при внесении в почву новых для агроценоза видов отмечали еще Л.Г. Данилов с соавт. (41), но в этом случае в яблоневом саду применяли обработку приствольных кругов биопрепаратами на основе суспензий энтомопатогенных нематод. Имеются данные, например сообщение N. Somasekhar с соавт. (46), о положительном влиянии вносимых при обработках штейнерматид на аборигенные виды нематод, обитающих в почвах агроценозов.

После проведения экспериментов нематоды St. carpocapsae были также выявлены в почве зернопропашного севооборота ФНЦБЗР, причем патогены сохранялись не только в течение всего периода проведения исследования: в результате был создан устойчивый очаг инфекции, действующий на протяжении нескольких лет (см. табл. 3).

При сравнении числа нематод St. carpocapsae, отловленных на тест-объект, с аналогичными показателями на участках, где проводилась традиционная защита от вредителей, прослеживалась положительная динамика, тогда как в контроле этого не наблюдалось (см. табл. 3).

3. Численность личинок Steinernema carpocapsae, отловленных в почве (биотест с Galleria melonella), при применении автодиссеминации с использованием

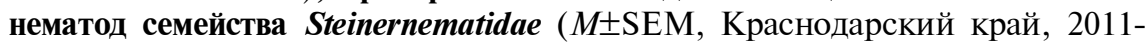
2015 годы)

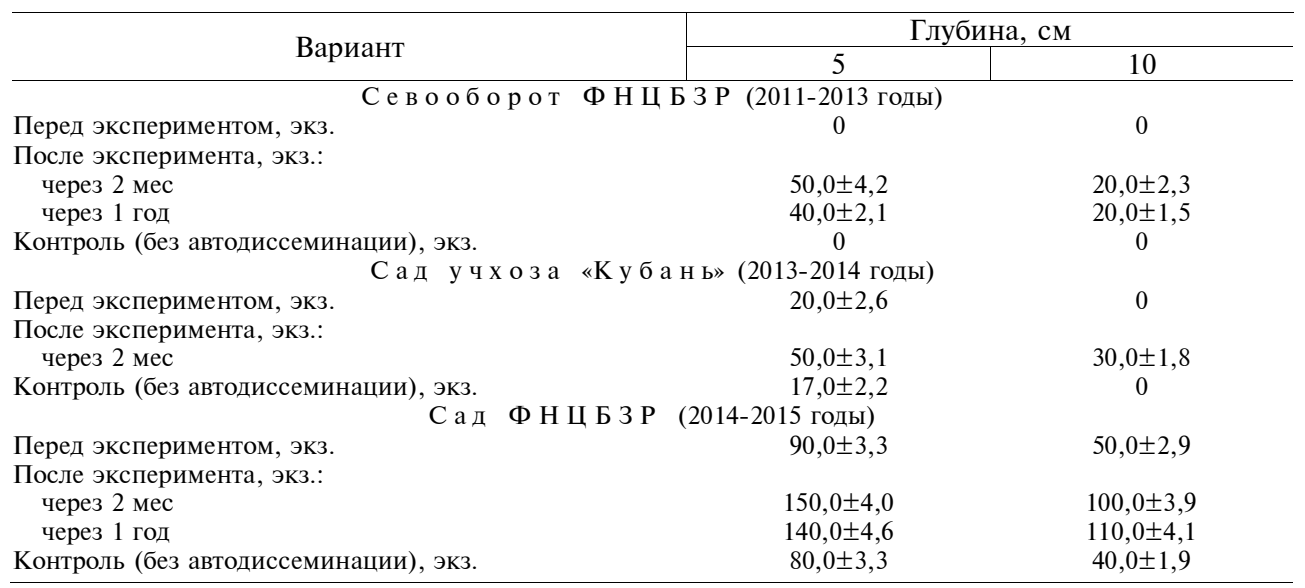

Таким образом, мы изучили возможность применения энтомопатогенных нематод семейства Steinernematidae для защиты кукурузы, сои и яблоневого сада от ряда вредителей с помощью метода автодиссеминации. Установлено, что распространяемые путем автодиссеминации энтомопатогенные нематоды заражали 60,0-100 \% самцов жуков-щелкунов семейства Elateridae и 30,3-5,5 \% бабочек яблонной и восточной плодожорок, то есть предложенный метод пригоден для использования наряду с традиционными 
приемами внесения патогенов в агроэкосистемы. Это особенно актуально для органического сада, где запрещены любые химические инсектициды. Важно отметить, что использование автодиссеминации в яблоневом саду и севооборотах позволило затронуть определенные группы насекомых, не причиняя вреда полезным организмам, кроме того, на всех участках, где проводились испытания автодиссеминации, выявлено, что внесение в агроценоз нового вида патогена благоприятно влияло на инвазионную активность местных популяций энтомопатогенных нематод.

Мы выражсаем благодарность к.б.н. В.В. Костюкову за помощь в установлении видовой принадлежности энтомофагов из семейств Braconidae и Ichneuтопidae.

\section{ЛИТЕРАТ У РА}

1. Исмаилов В.Я., Агасьева И.С. Практическое использование синтетических феромонов основных вредителей яблони. Агро XXI, 2003, 1-6: 72-74.

2. Kirsch Ph. Pheromones: their potential role in control of agricultural insect pests. American Journal of Alternative Agriculture, 1988, 3(2-3): 83-97 (doi: 10.1017/S0889189300002241).

3. Pluciennik Z. The control of codling moth (Cydia pomonella L.) population using mating disruption method. Journal of Horticultural Research, 2013, 21(1): 65-70 (doi: 10.2478/johr-2013-0009).

4. Stelinski L.L., Gut L.J., Haas M., McGhee P., Epstein D. Evaluation of aerosol devices for simultaneous disruption of sex pheromone communication in Cydia pomonella and Grapholita molesta (Lepidoptera: Tortricidae). Journal of Pest Science, 2007, 80(4): 225-233 (doi: 10.1007/s10340007-0176-7).

5. Vernon R.S., Toth M. Evaluation of pheromones: a new trap for monitoring Agriotes lineatus and Agriotes obscurus in the Fraser Valley of British Columbia. Journal of Chemical Ecology, 2007, 33(2): 345-351 (doi: 10.1007/s10886-006-9217-6).

6. Надыкта В.Д., Ниязов О.Д., Иванова Т.С., Пастарнак И.Н., Пачкин А.А. Дезориентация как метод регулирования численности яблонной плодожорки. Политематический электронный журнал КубГАУ, 2012, 1(36): 106-109.

7. Charmillot P.-J., Degen Th., Pasquier D., Briand F. New pheromone-based methods for grape moth control. Journal of Pest Science, 2005, 73(5): 283-288 (doi: 10.1007/s10886-016-0722-y).

8. Tokumaru S., Abe Y. Interspecific hybridization between Liriomyza sativae Blanchard and L. trifolii (Burgess) (Diptera: Agromyzidae). Applied Entomology and Zoology, 2005, 40(4): 551-555 (doi: 10.1303/aez.2005.551).

9. Howse P., Armsworth C., Baxter I. Autodissemination of semiochemicals and pesticides: a new concept compatible with the sterile insect technique. In: Area-wide control of insect pests /M.J.B. Vreysen, A.S. Robinson, J. Hendrichs (eds.). Springer, Dordrecht, 2007: 275-281 (doi: 10.1007/978-1-4020-6059-5_26).

10. Шамшев И.В., Гричанов И.Я. Место феромонов в фитосанитарных технологиях. Защита и карантин растений, 2008, 7: 22-23.

11. Цветкова В.П., Поддубная Е.Н., Исмаилов В.Я., Журавлев С.В. Феромониторинг яблонной плодожорки - основа защитных мероприятий в садах Западной Сибири. Вестник Новосибирского ГАУ, 2008, 7: 12-22.

12. Sukovata L., Czokajlo D., Kolk A., lusarski Sł., Jabłoński T. An attempt to control Cameraria ohridella using an attract-and-kill technique. Journal of Pest Science, 2010, 11: 111-115 (doi: 10.1007/s10340-010-0342-1).

13. Sumedrea M., Marin F.C., Calinescu M., Sumedrea D., Iorgu A. Researches regarding the use of mating disruption pheromones in control of apple codling moth - Cydia pomonella L. Agriculture and Agricultural Science Procedia, 2015, 6: 171-178 (doi: 10.1016/j.aspro.2015.08.055).

14. Сугоняев Е.С., Дорошенко Т.Н., Яковук В.А., Балахнина И.В., Шевченко О.С., Васильева Л.А. Апробация программы экологического управления популяциями вредных и полезных видов членистоногих в экосистеме яблоневого сада. Наука Кубани, 2010, 2: 42-47.

15. Джадд Г.Дж.Р. Применение семиохимических соединений в целях автодиссеминации энтомопатогенов, применяемых в целях контроля яблонной плодожорки: возможности и ограничения. Мат. межд. науч.-практ. конф. «Биологическая защита растений - основа стабилизации агроэкосистем». Краснодар, 2006, вып. 4: 92-93.

16. Исмаилов В.Я., Пачкин А.А., Агасьева И.С. Новые технологии управления численностью вредных видов с помощью феромонов и энтомопатогенов. Мат. межд. науч.-практ. конф. «Биологическая защита растений - основа стабилизации агроэкосистем». Краснодар, 2012, вып. 7: 221-224.

17. Данилов Л.Г. Методические подходы к изучению особенностей биологии энтомопатогенных 
нематод (Rhabditida: Steinernematidae, Haterorhabditidae) и технологические решения их эффективного использования в качестве средств биологической защиты растений. СПб, 2003.

18. Штерншис М.В. Энтомопатогены - основа биопрепаратов для контроля численности фитофагов. Новосибирск, 2010.

19. Mohan Sh. Entomopathogenic nematodes and their bacterial symbionts as lethal bioagents of Lepidopteran pests. Biocontrol of Lepidopteran Pests, 2015, 43(1): 273-288 (doi: 10.1007/978-3319-14499-3_13).

20. Divya K., Sankar M. Entomopathogenic nematodes in pest management. Indian Journal of Science and Technology, 2009, 2(7): 53-60 (doi: 10.17485/ijst/2009/v2i7/29499).

21. Спиридонов С.Э. Применение энтомопатогенных нематод в защите растений. В сб.: Прикладная нематология /Под ред. С.В. Зиновьева, В.Н. Чижова. М., 2006: 291-311.

22. Shapiro-Ilan D.I., Morales-Ramos J.A., Rojas M.G. In vivo production of entomopathogenic nematodes. Methods in Molecular Biology, 2016, 1477: 137-158 (doi: 10.1007/978-1-4939-6367$\left.6 \_11\right)$.

23. Koneru S.L., Salinas H., Flores G.E., Hong R.L. The bacterial community of entomophylic nematodes and host beetles. Molecular Ecology, 2016, 25(10): 2312-2324 (doi: 10.1111/mec.13614).

24. Данилов Л.Г. Особенности инвазирования и последующего развития нематод Neoaplectana carpocapsae штамм «агриотос» при свободном контакте паразита с хозяином. В сб.: Гельминты насекомых. М., 1980: 42-46.

25. Данилов Л.Г., Айрапетян В.Г. Инсектициды на основе энтомопатогенных нематод. Защита и карантин растений, 2012, 8: 39-43.

26. Liu J., Poinar G.O. Jr., Berri R.E. Control of insect pests with entomopathogenic nematodes: the impact of molecular biology and phylogenetic reconstruction. Annual Review of Entomology, 2000, 45(1): 287-306 (doi: 10.1146/annurev.ento.45.1.287).

27. Спиридонов С.Э. Энтомопаразитические и энтомопатогенные нематоды. В кн.: Патогены насекомых: структурные и функциональные аспекты /Под ред. В.В. Глупова. М., 2001.

28. Эль-Диб А.М.А. Получение препаратов энтомопатогенных нематод и оценка их эффективности. Вестник Российского университета дружбы народов. Серия: Агрономия и животноводство, 2010, 3: 24-28.

29. Navaneethan Th., Strauch O., Besse S., Bonhomme A., Ehlers R.-U. Influence of humidity and a surfactant-polymer-formulation on the control potential of the entomopathogenic nematode Steinernema feltiae against diapausing codling moth larvae (Cydia pomonella L.) (Lepidoptera: Tortricidae). BioControl, 2010, 55(6): 777-788 (doi: 10.1007/s10526-010-9299-5).

30. Cruz-Martínez H., Ruiz-Vega J., Matada Mas-Ortíz P.T., Cortés-Martínez C.I., Osas-Diaz J.R. Formulation of entomopathogenic nematodes for crop pest control - a review. Plant Protection Science, 2017, 53(1): 15-24 (doi: 10.17221/35/2016-PPS).

31. Штерншис М.В., Андреева И.В., Цветкова В.П. Проблемы оптимизации энтомопатогенных биопрепаратов для защиты растений. Вестник Новосибирского ГАУ, 2011, 1(17): 7-12.

32. Lavelle P. Diversity of soil fauna and ecosystem function. Biology International, 1996, 33: 3-16.

33. Yeates G.W. Nematodes as soil indicators: functional and biodiversity aspects. Biology and Fertility of Soils, 2003, 37(4): 199-210 (doi: 10.1007/s00374-003-0586-5).

34. Grubisic D., Gotlin T., Juran I. Biological control of codling moth, Cydia pomonella Linnaeus 1785 (Lepidoptera: Tortricidae) using entomopathogenic nematode Steinernema carpocapsae Weiser 1955 (Rhabditida: Steinernematidae). Entomologia Croatica, 2010, 14 (3-4): 63-74.

35. Исмаилов В.Я., Пушня М.В. Перспективы использования метода автодиссеминации для защиты сельскохозяйственных культур от щелкунов рода Agriotes. Mam. межд. науч.-nракт. конф. «Биологическая защита растений - основа стабилизации агроэкосистем». Краснодар, 2012, вып. 7: 228-230.

36. Агасьева И.С., Пушня М.В. Культивирование энтомопатогенной нематоды Neoaplectana carpocapsae на различных насекомых-хозяевах. Мат. Всероссийского науч.-практ. сов. «Экологически безопасные и беспестициные технологии получения растениеводческой продукциџ.. Краснодар, 1994: 220-223.

37. Атанасов А.З. Семейство Ichneumonidae - Ихневмониды. В кн.: Определитель насекомых европейской части СССР /Под ред. А.З. Атанасова, В.П. Йонайтиса, Д.Р. Каспаряна, В.С. Куслицкого, А.П. Расницына, У.В. Сийтана, В.П. Толканица. Л., 1981, Т. ІІІ, Ч. 3.

38. Белокобыльский С.А. Семейство Braconidae - Бракониды. В кн.: Oпределитель насекомых Дальнего Востока России /Под ред. С.А. Белокобыльского, В.И. Тобиаса. Владивосток, 2000, T. IV, Ч. 4.

39. Доспехов Б.А. Методика полевого опыта. М., 1985.

40. Ивахненко О.А., Иванова Т.С. Оценка эффективности энтомопатогенных нематод в регулировании численности вредителей сельскохозяйственных культур в Краснодарском крае. Мат. межд. науч.-практ. конф. «Биологическая защита растений - основа стабилизации агроэкосистем». Краснодар, 2006, вып. 4: 234-235.

41. Данилов Л.Г., Махоткин А.Г., Васильев С.В., Турицин В.С. Взаимодействие Steinernema 
carpocapsae с фауной членистоногих и природными популяциями энтомопатогенных нематод в биотопе плодового сада. Паразитология, 2008, 42(1): 129-137.

42. El-Sufty R., Al Bgham S., Al-Awash S., Shahdad A., Al Bathra A. A trap for auto-dissemination of the entomopathogenic fungus Beauveria bassiana by red palm weevil adults in Date Palm Plantations. Egyptian Journal of Pest Control, 2011, 21(2): 271-276.

43. Benvenuti C., Barzanti G.P., Marianelli L., Sabbatini Peverieri G., Paoli F., Bosio G., Venanzio D., Giacometto E., Roversi P.F. A new device for auto-disseminating entomopathogenic fungi against Popillia japonica: a study case. Bulletin of Insectology, 2019, 72(2): 219-225.

44. Shapiro-Ilan D.I., Han R., Dolinksi C. Entomopathogenic nematode production and application technology. Journal of Nematology, 2012, 44(2): 206-217.

45. Cortés-Martínez C.I., Chavarría-Hernández N. Production of entomopathogenic nematodes in submerged monoxenic culture: a review. Biotechnology and Bioengineering, 2020, 117(12): 39683985 (doi: 10.1002/bit.27515).

46. Somasekhar N., Grewal P.S., De Nardo E.A.B., Stinner B.R. Non-target effects of entomopathogenic nematodes on the soil nematode community. Journal of Applied Ecology, 2002, 39(5): 735744 (doi: 10.1046/j.1365-2664.2002.00749.x).

ФГБНУ Федеральный научный центр биологической защиты растений, Поступила в редакцию 350039 Россия, г. Краснодар, ул. Вавилова, 14, 27 апреля 2021 года e-mail: mar.pushnya2014@yandex.ru $\bowtie$, vlyaism@yandex.ru, balakhnina@yandex.ru, rigaeyu@gmail.com, greas23@yandex.ru, alex.agro83@mail.ru

Sel'skokhozyaistvennaya biologiya [Agricultural Biology], 2021, V. 56, № 3, pp. 523-536

\title{
BIOCONTROL OF AGRICULTURAL PESTS BASED ON AUTODISSEMINATION OF ENTOMOPATHOGENIC NEMATODES OF Steinermatidae FAMILY (Nematoda: Rhabditida)
}

\author{
M.V. Pushnya ${ }^{\bowtie}$, V.Ya. Ismailov, I.V. Balakhnina, E.Yu. Rodionova, E.G. Snesareva, \\ A.A. Komantsev
}

Federal Research Centre of Biological Plant Protection, 14, ul. Vavilova, Krasnodar, 350039 Russia, e-mail mar.pushnya2014@yandex.ru ( $\bowtie$ corresponding author), vlyaism@yandex.ru, balakhnina@yandex.ru, rigaeyu@gmail.com, greas23@yandex.ru, alex.agro83@mail.ru

ORCID:

Pushnya M.V. orcid.org/0000-0002-7133-9533

Ismailov V.Ya. orcid.org/0000-0002-6713-0059

Balakhnina I.V. orcid.org/0000-0002-2326-221X

Rodionova E.Yu. orcid.org/0000-0001-5631-2204

Snesareva E.G. orcid.org/0000-0003-4617-3604

The authors declare no conflict of interests

Komantsev A.A. orcid.org/0000-0003-1136-3264

Acknowledgments:

We are grateful to Ph.D. V.V. Kostyukov for help in identifying the species of entomophages of the families Braconidae and Ichneumonidae.

The research was carried out within the framework of the State Assignment of the Ministry of Science and Higher Education of the Russian Federation (the topic No. 0686-2019-0010)

Received April 27, 2021

doi: 10.15389 /agrobiology.2021.3.523eng

\section{Abstract}

At present, the development of biological plant protection systems is among the most important economic, social and environmental challenges. Creating an effective system is impossible without the combination of a variety of biological agents and pest control techniques. Combining a variety of pathogenic organisms and synthetic sex pheromones is a way to improve the situation. This paper shows the effectiveness of entomopathogenic nematodes (EPN) of the family Steinernematidae Filipjev, 1934 as an autodissemination agent for agro-ecosystems under crop rotation and at apple-tree orchard, and assessed the effect of introducing pathogens on indigenous entomopathogens in soil. In particular, a decrease in the number of harmful insects and an increase in the activity of natural beneficial entomopathogens have been demonstrated. The essence of the method consists in the targeted introduction of entomopathogenic bioagents into the agro-ecocenosis by means of their application to attracted insects caught in traps, and thus creating an epizootic in the populations of target species. Previously, entomopathogenic nematodes were not used as autodissemination agents against superdominant species, the codling moth Cydia pomonella L., 1758 and click beetles of the family Elateridae Leach, 1815; moreover, their effect on other members of the entomofauna of agro-ecocenoses has not been studied either. The purpose of this work was to evaluate the effectiveness of the EPN autodissemination method for various cultures. The successful testing of Granulosis virus dissemination method in the apple orchard and the EPN autodissemination against wireworms prompted us 
to conduct the investigation reported herein. Two species of entomopathogenic nematodes of Steinernematidae family, the Steinernema carpocapsae (Weiser, 1955) and St. feltiae (Filipiev, 1934) were reproduced in lab culture in different host insects to produce nematode inoculums. The experiments found out that specially designed formulations and modified pheromone traps ensure EPN introduction into the agrocenoses due to nematode invasion of trapped insects followed by their free flight to spread pathogens. As a result, the nematode-bacteria complex occurred in $60.0-100 \%$ of click beetles of the Elateridae family and 34.0-35.3\% of C. pomonella L. and Grapholitha molesta (Busck, 1916). This indicates accumulation of biocontrol agents in the soil of the agrocenoses due to EPN introduction. The EPN autodissemination application also reduced the damage to apple fruits by up to $10 \%$, and corn and soybean plants by $13,2 \%$ compared to areas where chemical treatments were applied. The method has no negative impact of EPN on green lacewings (Chrysopidae Schneider, 1851) and the Hymenoptera of the families Braconidae, Latreille, 1829 and Ichneumonidae, Latreille, 1802, the predators of insect pests. In the garden where the tests were carried out, there was a $15 \%$ increase in infection of caterpillars of C. pomonella by Hymenoptera. It is established that the EPN autodissemination stimulates the activity of indigenous soil EPN, leading to a 1.5-2.0-fold increase in the number of trapped nematodes in the bioassay test compared to the period prior to EPN autodissemination. Importantly, the effect of autodissemination turned out to be prolonged and manifested the next year both in the apple orchard and in the crop rotation of agricultural crops.

Keywords: biocontrol, entomopathogenic nematodes, autodissemination, soil nematodes, codling moth, click beetles, wireworms, pheromone traps, apple trees, maize, soybean. 